\title{
Monosodium Glutamate Toxic Effect on Spleen Structure and Potentiality of Recovery in Adult Albino Rats
}

\author{
Hala M. Ebaid and Hend M. Tag \\ Department of Zoology, Faculty of Science, Suez Canal University \\ Email halaebaid@yahoo.com
}

\begin{abstract}
Histological effects of Monosodium glutamate (MSG) commonly used as food additive on the spleen of adult Wistar rats were carefully studied. The rats $(n=30)$, average weight of $115 \mathrm{gm}$ were randomly assigned into four treatments $(\mathrm{n}=6)$ and control $(n=6)$ groups. The rats in the treatment groups received $4 \mathrm{mg} / \mathrm{kg}$ IP of MSG for fourteen days, while the control group receives the same volume of distilled water intraperitoneally. The rats were sacrificed after the last day of injection (group 1) and on 14 (group 2), 28 (group 3) and 42 day (group 4) after cessation of the treatment with MSG. The spleen was carefully dissected out and quickly fixed in $10 \%$ buffered formaldehyde for routine histological study after H\&E method. The histological findings after H\&E methods for group 1 indicated that the treated sections of the spleen showed atrophy of the while pulp, germinate centers were missing and red pulp of the spleen showed aplasia. The treatment (Group 2) showed vacuolation of some splenic cells with decreased cellularity, and sinusoidal spaces were large. Animals of group 3 showed slight atrophy in the white pulp and aplasia of red pulp where it began to retain normal structure. In the animals sacrificed at the end of the experimental period, the spleen retained its normal structure. These findings indicate that MSG consumption may have some deleterious effects on the spleen of adult Wistar rats which is reversible and does not lead to permanent damage but the normal structure of the spleen would need a long time to be regained. It is recommended that further studies aimed at corroborating these findings be carried out.
\end{abstract}

Key words: Monosodium glutamate, Rat, Spleen

\section{INTRODUCTION}

Most food additives act either as preservatives or enhancer of palatability, one of such food additives is monosodium glutamate (MSG), which generated much controversy locally and globally about its safety usage (Moore, 2003). Monosodium glutamate, which is chemically known as AJI-NO-MOTO, is one of the most common amino acids found in nature (Adrienne, 1999). Vinodini et. al. (2008) defined (MSG) as a sodium salt of naturally occurring non-essential L-form of glutamic acid, and as one of the main flavor enhancer used as an ingredient in various food products.

It is also produced in the body and plays an essential role in human metabolism. It is a major component of many proteins such as meat, fish, milk and some vegetables (IFIC, 1994). Despite its taste stimulation and improved appetite enhancement, reports indicated that MSG is toxic to human and experimental animals (Andrew, 2007). It contains exitoxins like most of the taste-enhancing additives, as mentioned by (Russel and Blaylock, 1994) who defined exitoxins as a group of excitatory amino acids, they also mentioned that although they are widely distributed in our food supply, we may not be able to depend on the food and drug administration (FDA) to protect us from these toxins because of the powerful food lobby known as 
the glutamate association which counteract any negative reports or publicity of research showing the harmful effects of MSG.

Glutamate in high doses produce neuroendocrine abnormalities and neuronal degeneration (Moreno et al., 2005), and oxidative damage in different organs (Farmobi and Onyemia, 2006; Pavlovic et al., 2007).

The spleen, the largest secondary lymphoid organ, is considered the draining site for compounds that are administered intravenously, and is therefore considered an important organ to evaluate for treatment-related lesions. Due to the presence of B and $\mathrm{T}$ lymphocytes, the immunotoxic effects of xenobiotics or their metabolites on these cell populations may be reflected in the spleen. Therefore, it is one of the recommended organs to evaluate for enhanced histopathology of the immune system (Elmore, 2006).

Previous scientific investigations aimed at determining the effect of MSG on body organs (Nwaopara et al., 2004; 2007a, b; 2008a, b). There are some reports of the toxic effects of MSG on the pancreas (Nwaopara et al., 2004), liver (Nwaopara et al., 2007b) and kidney (Nwaopara et al., 2008 a). The aim of the present study was to go more into the toxic effects of MSG administration on the histopathological changes in spleen of albino rats and to determine possibility of reversibility of these effects.

\section{MATERIAL AND METHODS}

\section{(a) Experimental animals}

This study was performed on thirty young adult Wistar male rats (age 10 weeks), weighing about 100-130 gm. The animals were bred and maintained under standardized conditions away from any stressful conditions with 12:12 light: dark cycle with free access to food and water in the animal house. They were acclimatized for one week prior to the experiment and caged six per cage in fully ventilated room at room temperature. All experimental procedures and animal maintenance were conducted in accordance with the accepted standards of animal care.

\section{(b) Tested compound}

Monosodium glutamate (MSG) was purchased from Roth Company, Germany. MSG was in the form of small pellets and before usage, it was dissolved in distilled water, $1 \mathrm{gm}$ of MSG in $1 \mathrm{ml}$ of distilled water (Nayatara et al., 2008).

\section{(c) Experimental design}

The animals were divided randomly into 5 groups; each included 6 rats. The experimental design is to be seen in Table (1).

Table 1: Experimental design

\begin{tabular}{ccccc}
\hline $\begin{array}{c}\text { Experimental } \\
\text { group }\end{array}$ & Treatment & No. of animals & Dose & \multicolumn{1}{c}{ Duration } \\
\hline Control & distilled water & 6 & $0.1 \mathrm{ml} \mathrm{I.P}$ & \multicolumn{1}{c}{ daily for 14 days } \\
\hline Group 1 & MSG group & 6 & $4 \mathrm{mg} / \mathrm{Kg} \mathrm{.b.w} \mathrm{I.P} \begin{array}{l}\text { Administrated daily for 14 days } \\
\text { and the animals were sacrificed } \\
\text { after the last day of injection }\end{array}$ \\
\hline Group 2 & Recovery 1 & 6 & $4 \mathrm{mg} / \mathrm{Kg}$. b.w I.P & $\begin{array}{l}\text { Administrated daily for 14 days } \\
\text { and the animals were sacrificed 2 } \\
\text { weeks after stoppage of the } \\
\text { treatment }\end{array}$ \\
\hline Group 3 & Recovery 2 & 6 & $4 \mathrm{mg} / \mathrm{Kg}$. b.w I.P & $\begin{array}{l}\text { Administrated daily for 14 days } \\
\text { and the animals were sacrificed } 4 \\
\text { weeks after stoppage of the } \\
\text { treatment }\end{array}$ \\
\hline Group 4 & Recovery 3 & 6 & $\begin{array}{l}\text { Administrated daily for 14 days } \\
\text { and the animals were sacrificed } 6 \\
\text { weeks after stoppage of the } \\
\text { treatment }\end{array}$ \\
\hline
\end{tabular}




\section{(d) Histological procedures}

At the end of the experimental period, the animals were sacrificed by cervical section. Pieces of spleen were excised, rinsed in physiological saline and fixed in formalin saline for 24 hours. The preserved organs were cut into smaller portions for processing, dehydrated with isopropyl alcohol, cleared with terpinole, infiltrated and embedded with paraffin wax. Paraffin wax blocks were sectioned at $5 \mu$ thick with a rotary microtome using a disposable blade. Sectioned slides were stained with Harris' haematoxylin and eosin (H\&E) (Luna, 1968) and mounted with (DPX). Six sections of spleen from each animal were examined by light microscope.

\section{RESULTS}

The structure of control spleen was composed of white and red pulps surrounded by a capsule of dense connective tissue (Figs. A and B). The white pulp was composed of a central, T-cell rich zone, and a peri-arterial lymphoid sheath surrounded by B-cell-rich primary follicles. The white pulp was separated from the red pulp by the marginal zone lymphocytes.

Pathohistologically, the experimental animals sacrificed after the last day of injection (Group 1) displayed that the limit between white and red pulp started to disappear, besides depletion of lymphocytes within the white pulp and the absence of germinate centers (Fig. C). The animals which sacrificed 2 weeks after stoppage of the treatment (Group 2) showed vacuolation of some splenic cells with decreased cellularity, and sinusoidal spaces were large (Fig. D). Animals sacrificed 4 weeks after stoppage of the treatment (Group 3) showed slight atrophy in the white pulp and aplasia of red pulp where it began to retain normal structure (Fig. E). In the animals sacrificed at the end of the experimental period, the spleen retained its normal structure with where the marginal zone between white pulp and red pulp were well definite (Fig. F).

\section{DISCUSSION}

The safety of MSG usage has been generated much controversy locally and globally (Redding et al., 1971 and Pizzi et al., 1977). This study aims to investigate the effect of MSG on rat spleen and the possibility of recovery after cessation of the treatment. Till the time of starting the experiment, no studies were reported investigating the possibility of recovery after stopping the treatment with MSG.

MSG improves the palatability of meals and thus influences the appetite centre positively causing increase in body weight (Rogerset al., 1990). Though MSG improves taste stimulation and enhances appetite, reports indicate that it is toxic to human and experimental animals (Belluardo et al., 1990). MSG has a toxic effect on many body organs by altering ionic permeability of neural membrane and induces persistent depolarization (Robinson, 2006).

The results $(\mathrm{H} \& \mathrm{E})$ reactions revealed that animals treated with monosodium glutamate showing cellular disruption and degeneration of the white pulp in spleen as compared to the control sections. But after cessation of the treatment with MSG, there was varying degrees of cellular recovery which improved with time. Our result is in agreement with Ćirić et al. (2005) that administration of MSG induced degenerative and atrophic changes in rat spleen.

Recent studies have shown that glutamate receptors play very important role in pathogenesis of disorders induced by MSG. Glutamate is predominant excitatory 
neurotransmitter in the mammalians central nervous system (Schlett, 2006; Greenwood and Connolly, 2007; Liguz-Lecznar and Skangiel-Kramska, 2007). There are two basic types of glutamate receptors: ionotropic (NMDA, kainite and AMPA) and metabotropic (mGluR) (Smith et al., 2001; Weston et al., 2006; Gerber et al., 2007).

Neurotoxicity of MSG is related with glutamate receptors activation (Gao et al., 1994; Beas-Zarate et al., 2001). Such excessive activation of glutamate receptors and overloading with intracellular calcium can induce neural death (Gil-Loyzaga et al., 1993). Glutamate receptors are present in different tissues: hypothalamus, spleen, thymus, liver, kidneys, endocrine system, ovaries, etc. (Gill and Pulido, 2005; Gill et al., 2008).

Our results may support that reported by Fallarino et al. (2010) who demonstrated that Glutamate might affect neuroinflammation via effects on immune cells. Knockout mice lacking metabotropic glutamate receptor-4 (mGluR4) were markedly vulnerable to experimental autoimmune encephalomyelitis (EAE, a mouse model of multiple sclerosis) and developed responses dominated by interleukin-17producing $\mathrm{T}$ helper $\left(\mathrm{T}_{\mathrm{H}} 17\right)$ cells.

Based on the obtained results, the conclusion may be drawn that the administration of monosodium glutamate to animals leads to reversible atrophy of cells of both white and red pulp, which explains the immunosuppressive effects of glucocorticoids.

\section{REFERENCES}

Adrienne, S. 1999. The toxicity-Safety of MSG. Acct. Res. 6(4): 259-310.

Andrew, O.E. 2007. Histological studies of the effects of monosodium glutamate on the kidney of adult Wistar rats. The internet journal of health. Vol 6, No. 2.

Beas-Zárate, C., Rivera-Huizar, S.V., Martinez-Contreras, A., Feria-Velasco, A. and Armendariz-Borunda, J. 2001. Changes in NMDA-receptor gene expression are associated with neurotoxicity induced neonatally by glutamate in the rat brain. Neurochem. Int. 39: 1-10.

Belluardo, M., Mudo, G. and Bindoni, M. 1990. Effect of early destruction of the mouse arcuate nucleus by MSG on age dependent natural killer activity: Brain Res., 534: 225-333.

Ćirić, M., Cekić, S., Pavlović, V., Jović, Z. and Tasić, G. 2005. Histopathological Changes In The Spleen Of Rats Treated With Monosodium Glutamate. ACTA FAC. MED. NAISS. 22(4): 191-194.

Elmore, S.A. 2006. Enhanced Histopathology of the Spleen. Toxicol Pathol. 34(5): $648-655$.

Fallarino, F., Volpi, C., Fazio, F., Notartomaso, S., Vacca, C., Busceti, C., Bicciato, S., Battaglia, G., Bruno, V., Puccetti, P., Fioretti, M.C., Nicoletti, F., Rohmann, U. and Di Marco, R. 2010. Metabotropic glutamate receptor-4 modulates adaptive immunity and restrains neuroinflammation. Nature Medicine, (16) 897-902.

Farmobi, E.O. and Onyema, O.O. 2006. Monosodium glutamate-induced oxidative damage and genotoxicity in the rat: Modulatory role of vitamin C, vitamin $\mathrm{E}$ and quercetin. Hum.Exp.Toxicol., 25: 251-259.

Gao, J., Wu, J., Zhao, X.N., Zhang, W.N., Zhang, Y. and Zhang, Z.X. 1994. Transplacental neurotoxic effects of monosodium monosodium glutamate on 
structures and functions of specific brain areas of filial mice. Sheng Li Xue Bao, 46: 44-51 (in Chinese).

Gerber, U., Gee, C.E. and Benquet, P. 2007. Metabotropic glutamate receptors: intracellular signaling pathways. Curr.Opin.Pharmacol., 7: 56-61.

Gill, S. and Pulido, O. 2005. Glutamate receptors in peripheral tissue excitatory transmission out side the CNS. Kulwer Academic/Plenum Publisher, NewYork.

Gill, S., Barker, M. and Pulido, O. 2008. Neuroexcitatory targets in the female reproductive system of the nonhuman primate (Macaca fascicularis). Toxicol. Pathol. 36: 478-484.

Gil-Loyzaga, P., Hernandez-Ortiz, M.J., Rodriguez-Benito, T. and Lasso de la Vega, M. 1993. Diltiazem protects against neurotoxicity induced by excitotoxic amino acids on cochlear afferent fibers. J.Otorhinolaryngol.Relat., 55: 211-215.

Greenwood, S.M. and Connolly, C.N. (2007): Dendritic and mitochondrial changes during glutamate excitotoxicity. Neuropharmacology, 53: 891-898.

IFIC 1994. Review of monosodium glutamate, examining the Myths.

Liguz-Lecznar, M. and Skangiel-Kramska, J. 2007. Vesicular glutamate transporters (VGLUTs): the three musketeers of glutamatergic system. Acta Neurobiol.Exp. (Wars.), 67: 207-218.

Luna, G. 1968. Manual of Histological Staining Method of the Armed Forces Institute of Pathology. $3^{\text {rd }}$ ed., McGraw-Hill Book Company, New York.

Moore, K.L. 2003. Congenital malformations due to environment in developing humans. Second edition. Philadelphia: W.B. Saunders co. Ltd. Pp. 173-183.

Moreno, G., Perello, M., Gaillardand, R.C. and Spine, E. 2005. Orexin a stimulates hypothalamic- pituitv- adrenal (HPA) axis function, but not food intake in the absence of full hypothalamic NPY- ergic activity. Endocrine, 26: 99- 106.

Nayanatara, A.K., Vinodini, N.A., Ahemed, B., Ramaswamy, C.R., Shabarianth, G. and Ramesh Bhat, M. 2008. Role of ascorbic acid in monosodium glutamate mediated effect on testicular weight, sperm morphology and sperm count, in rat testis. Journal of Chinese Clinical Medicine, 3:1.

Nwaopara, A.O., Anyanwu, L.C., Oyinbo, C.A. and Anaikot, I.C. 2004. The histological changes in pancreas of Wistar rats fed with diets containing Yaji (local meat sauce). J.Exp.Clin.Anat., 3: 44- 47.

Nwaopara, A.O., Oyinbo, M.A.C., Ikhuoriah, T.A. and Anyanwu, L.C. 2007a. Potential health hazards in Yaji: The complex suya meat sauce. Medilink J., 8: 34- 38 .

Nwaopara, A.O., Odike, M.A.C., Inegbenebor, U. and Adoye, M.I. 2007b. The combined effects of excessive consumption of ginger, clove, red pepper and black pepper on the histology of the liver. Pak.J.Nutr., 6: 524-527.

Nwaopara, A.O., Odike, M.A.C., Inegbenebor, U., Nwaopara, S.O. and Ewere, G.I. 2008a. A comparative study on the effects of excessive consumption of ginger, clove, red pepper and black pepper on the histology of the Kidney. Pak.J.Nutr., 7: 287-291.

Nwaopara, A.O., Odike, M.A.C., Inegbenebor, U., Nwaopara, S.O. and Ekhoye, E.I. 2008b. A comparative study disorders on the effects of excessive consumption of ginger, clove, red pepper and black pepper on the histology of the Heart. Electronic J,Biomedic., 3: 61- 64.

Pavlovic, V., Pavlovic, D., Kocic, D., Sokolovic, D. and Jevtovic-Stoimenov 2007. Effect of monosodium glutamate on oxidative stress and apoptosis in rat thymus. J.Mol.Cell Biochem., 303: 161-166. 
Pizzi, W.J., Barnhart, J .E. and Fanslow, D.J. 1977. Monosodium glutamate administration to the newborn reduces reproductive ability in female and male mice. Science, 196: 452-454.

Redding, T.W., Schally, A.V., Arimura, A. and Wakabayashi, I. 1971. Effect of monosodium glutamate on some endocrine functions. Neuroendocrinology, 8: 245-255.

Robinson, M.B. 2006. Acute regulation of sodium-dependent glutamate transporters: a focus on constitutive and regulated trafficking. Handb.Exp.Pharmacol., 175: 251-275.

Rogers, P.P., Blundell, J.E. and Umani, N. 1990. Effects of monosodium glutamate on hunger and food intake in human subjects. Physiol.Behav., 486: 801-804.

Russell, L. and Blaylock, F. 1994. Excitotoxins - The taste that kills. Health press, Santa Fe, NM. Book Review. ISBN: 0-929173-14-7.

Schlett, K. 2006. Glutamate as a modulator of embryonic and adult neurogenesis. Curr.Top.Med.Chem., 6: 949-960.

Smith, Y., Charara, A., Paquet, M., Kieval, J.Z., Paré, J.F., Hanson, J.E., Hubert, G.W., Kuwajima, M., Levey, A.I. 2001. Ionotropic and metabotropic GABA and glutamate receptors in primate basal ganglia. J.Chem.Neuroanat., 22: 13-42.

Vinodini, N.A.; Nayanatara, A.K.; Damodara Gowda, K.M.; Ahamed, B.; Ramaswamy, C.R. and Shabarinathand Ramesh Bhat, M. 2008. Effect of monosodium glutamate-induced oxidative damage on rat testis. Journal of Chinese Clinical Medicine, Vol.3, No.7.

Weston, M.C., Gertler, C., Mayer, M.L. and Rosenmund, C. 2006. Interdomain interactions in AMPA and kainate receptors regulate affinity for glutamate. J.Neurosci., 26: 7650-7658. 

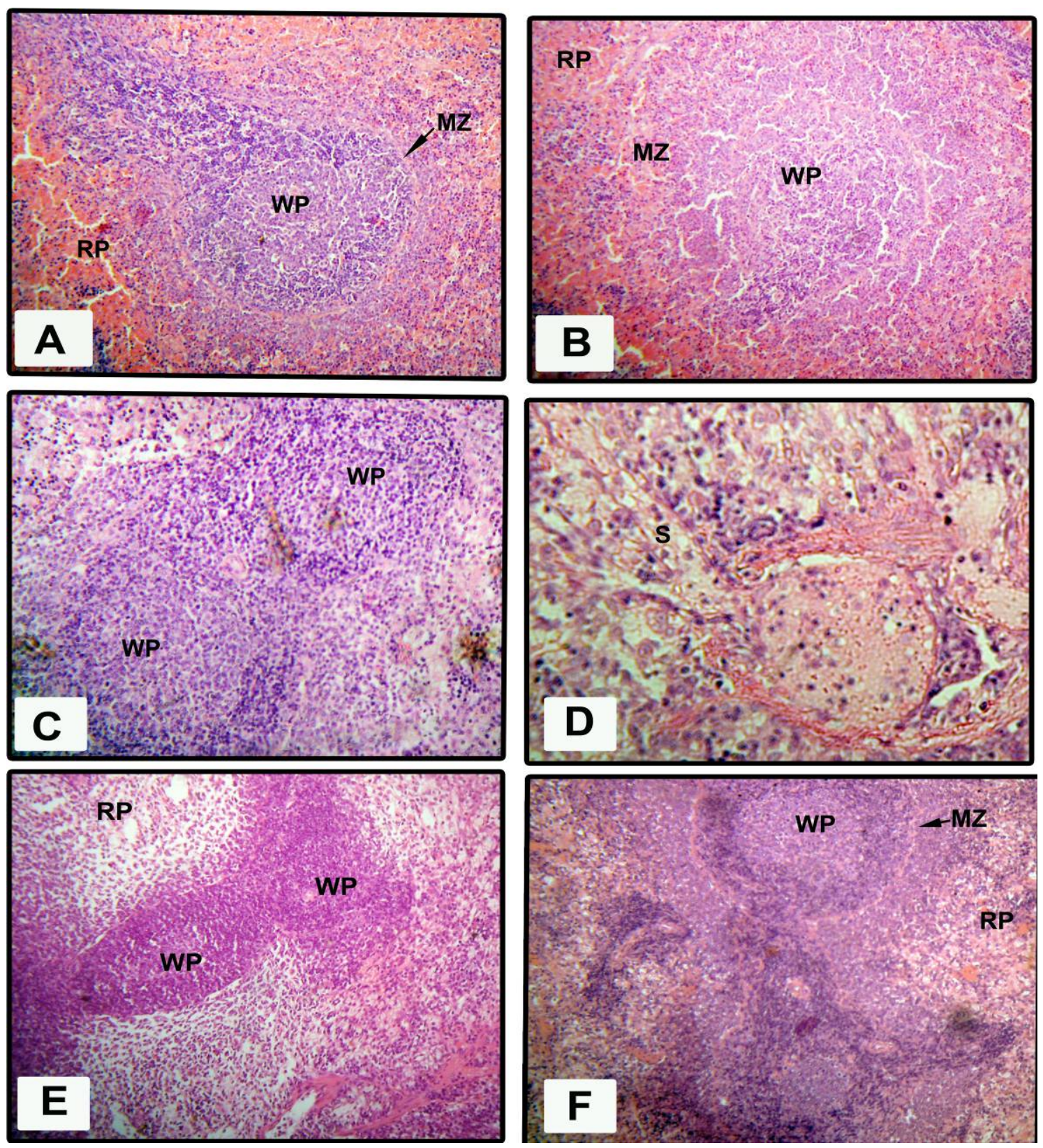

Figs. A, B: Normal spleen structure of control group, (WP) lymphatic follicles of the spleen, (RP) red spleen pulp and Marginal zone (MZ) (HE x20 and 40).

Fig. C: group 2 absence of germinate centers (HE x20).

Fig. D: group 3 showed vacuolation of some splenic cells and dilation of sinusoidal spaces (S) (HEx40).

Fig. E: group 3 atrophy in the white pulp (WP) and aplasia of red pulp (RP) (HE x20).

Fig. F: experimental group no. 4 splenic tissue retain normal structure (WP) lymphatic follicles of the spleen, (RP) red spleen pulp and Marginal zone (MZ) (HE x20). 


\section{ARABIC SUMMAEY}

التأثير السام لملح أحادي جلوتاميت الصوديوم على الطحال واحتمالات الثفاء منه في الجرذان البيضاء

هالة محمد عبيد و هند معروف تاج العماج

قسم علم الحيو ان - كلية العلوم - جامعة قناة السويس

\section{Email:halaebaid@yahoo.com}

تمت دراسة تأتير ملح أحادي جلوتاميت الصوديوم وهو من المواد واسعة الإنتشار من حيث الاستخدام

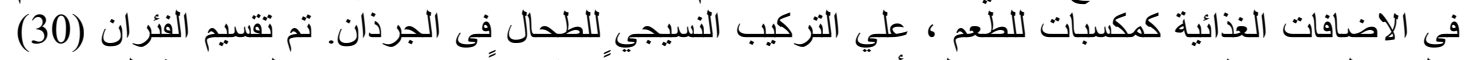

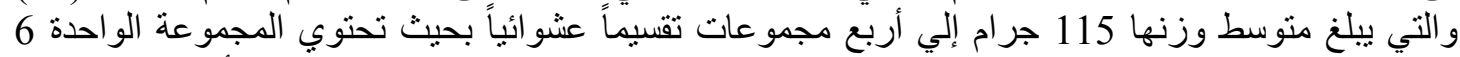

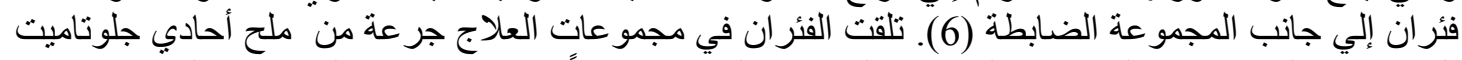

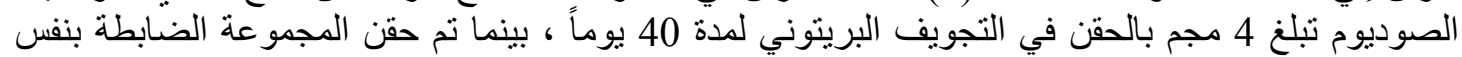

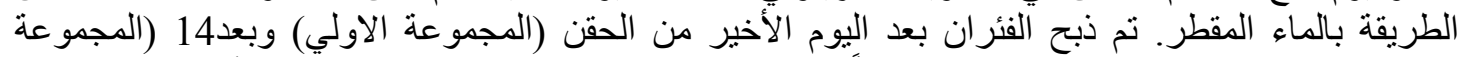

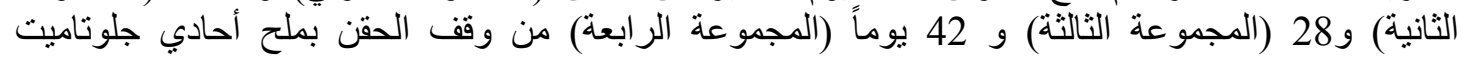

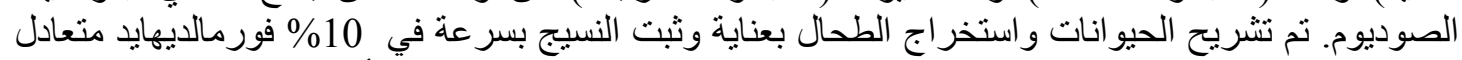

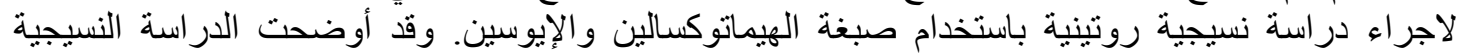

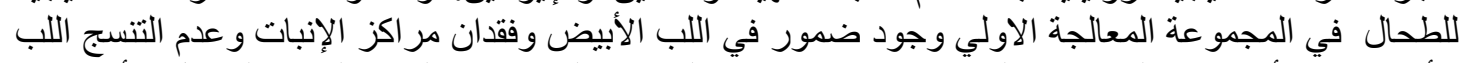

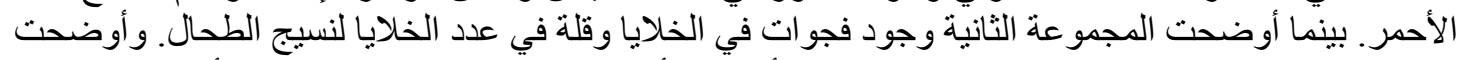

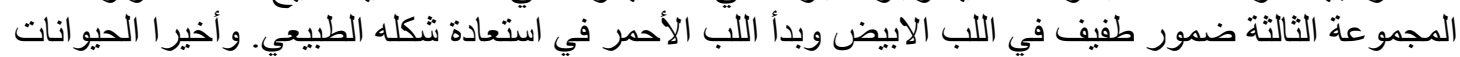

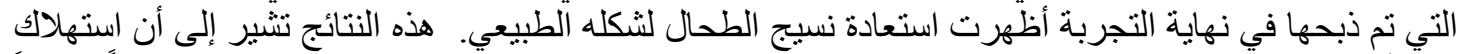

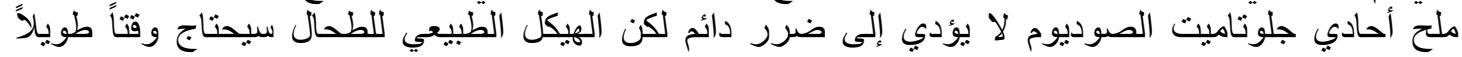

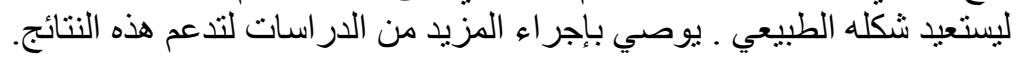

